\title{
Is there 1.5-million-year-old ice near Dome C, Antarctica?
}

\author{
Frédéric Parrenin $^{1}$, Marie G. P. Cavitte ${ }^{2,3}$, Donald D. Blankenship ${ }^{2}$, Jérôme Chappellaz $^{1}$, Hubertus Fischer ${ }^{4}$, \\ Olivier Gagliardini ${ }^{1}$, Valérie Masson-Delmotte ${ }^{5}$, Olivier Passalacqua ${ }^{1}$, Catherine Ritz ${ }^{1}$, Jason Roberts ${ }^{6,7}$, \\ Martin J. Siegert ${ }^{8}$, and Duncan A. Young ${ }^{2}$ \\ ${ }^{1}$ Univ. Grenoble Alpes, CNRS, IRD, IGE, 38000 Grenoble, France \\ ${ }^{2}$ Institute for Geophysics, Jackson School of Geosciences, University of Texas at Austin, Austin, Texas, USA \\ ${ }^{3}$ Department of Geological Sciences, Jackson School of Geosciences, University of Texas at Austin, Austin, Texas, USA \\ ${ }^{4}$ Climate and Environmental Physics, Physics Institute \& Oeschger Centre for Climate Change Research, University of Bern, \\ Bern, Switzerland \\ ${ }^{5}$ Laboratoire des Sciences du Climat et de l'Environnement, CEA-CNRS-UVSQ/IPSL - UMR8212, Gif-Sur-Yvette, France \\ ${ }^{6}$ Australian Antarctic Division, Kingston, 7050 Tasmania, Australia \\ ${ }^{7}$ Antarctic Climate \& Ecosystems Cooperative Research Centre, University of Tasmania, Hobart, 7001 Tasmania, Australia \\ ${ }^{8}$ Grantham Institute and Department of Earth Science and Engineering, Imperial College London, London, UK
}

Correspondence to: Frédéric Parrenin (frederic.parrenin@univ-grenoble-alpes.fr)

Received: 17 April 2017 - Discussion started: 3 May 2017

Revised: 30 August 2017 - Accepted: 11 September 2017 - Published: 2 November 2017

\begin{abstract}
Ice sheets provide exceptional archives of past changes in polar climate, regional environment and global atmospheric composition. The oldest dated deep ice core drilled in Antarctica has been retrieved at EPICA Dome C (EDC), reaching $\sim 800000$ years. Obtaining an older paleoclimatic record from Antarctica is one of the greatest challenges of the ice core community. Here, we use internal isochrones, identified from airborne radar coupled to ice-flow modelling to estimate the age of basal ice along transects in the Dome C area. Three glaciological properties are inferred from isochrones: surface accumulation rate, geothermal flux and the exponent of the Lliboutry velocity profile. We find that old ice ( $>1.5 \mathrm{Myr}, 1.5$ million years) likely exists in two regions: one $\sim 40 \mathrm{~km}$ south-west of Dome $\mathrm{C}$ along the ice divide to Vostok, close to a secondary dome that we name "Little Dome C" (LDC), and a second region named "North Patch" (NP) located 10-30 km north-east of Dome C, in a region where the geothermal flux is apparently relatively low. Our work demonstrates the value of combining radar observations with ice flow modelling to accurately represent the true nature of ice flow, and understand the formation of ice-sheet architecture, in the centre of large ice sheets.
\end{abstract}

\section{Introduction}

Since around 800000 years ago, glacial periods have been dominated by a $\sim 100000$-year cyclicity, as documented in multiple proxies from marine, terrestrial and ice core records (Elderfield et al., 2012; Jouzel et al., 2007; Lisiecki and Raymo, 2005; Loulergue et al., 2008; Lüthi et al., 2008; Wang et al., 2008; Wolff et al., 2006). These data have provided evidence of consistent changes in polar and tropical temperatures, continental aridity, aerosol deposition, atmospheric greenhouse gas concentrations and global mean sea level over numerous glacial cycles. Conceptual models (Imbrie et al., 2011) have been proposed to explain these asymmetric 100000 -year cycles in response to changes in the configuration of the Earth's orbit and obliquity (Laskar et al., 2004), and involve threshold behaviour between different climate states within the Earth system (Parrenin and Paillard, 2012). The asymmetry between glacial inceptions and terminations may, for example, be due to the slow build-up of ice sheets and their rapid collapse once fully developed due to glacial isostasy (Abe-Ouchi et al., 2013). Observed sequences of events and Earth system modelling studies (Fischer et al., 2010; Lüthi et al., 2008; Parrenin et al., 2013; Shakun et al., 2012) have shown that climate-carbon feed- 
backs also play a major role in the magnitude of glacialinterglacial transitions.

Critical to our understanding of these 100000 -year glacial cycles is the study of their onset, during the Mid-Pleistocene Transition (MPT; Jouzel and Masson-Delmotte, 2010), which occurred between 1250 and $700 \mathrm{kyr}$ BP thousands of years before 1950; Clark et al., 2006), and most likely during Marine Isotope Stages (MIS) 22-24, around $900 \mathrm{kyr}$ BP (Elderfield et al., 2012). Prior to the MPT, marine sediments (Lisiecki and Raymo, 2005) show glacial-interglacial cycles occurring at obliquity periodicities $(40 \mathrm{kyr})$ and with a smaller amplitude. The exact cause for this MPT remains controversial and several mechanisms have been proposed, including the transition of the Antarctic ice sheet from a wholly terrestrial to a part-marine configuration (Raymo et al., 2006), a hypothesis which is, however, unsupported by long-term simulations (Pollard and DeConto, 2009); a nonlinear response to weak eccentricity changes (Imbrie et al., 2011); merging of North American ice sheets (Bintanja and Van de Wal, 2008); changes in sea ice extent (Tziperman and Gildor, 2003); a time varying insolation energy threshold (Tzedakis et al., 2017); a threshold effect related to the atmospheric dust load over the Southern Ocean (MartínezGarcia et al., 2011); and a long-term decrease in atmospheric $\mathrm{CO}_{2}$ concentrations (Berger et al., 1999), the latter hypothesis being challenged by indirect estimates of atmospheric $\mathrm{CO}_{2}$ from marine sediments (Hönisch et al., 2009).

A continuous Antarctic ice core record extending back at least to $1.5 \mathrm{Myr}$ BP would shed new light on the MPT reorganisation (Jouzel and Masson-Delmotte, 2010), by providing records of Antarctic temperature, atmospheric greenhouse gas concentrations and aerosol fluxes prior to and after the MPT. The opportunity to measure cosmogenic isotopes $\left({ }^{10} \mathrm{Be}\right)$ would also provide information on changes in the intensity of the Earth's magnetic field, especially during the Jaramillo transition (Singer and Brown, 2002). Retrieving Antarctica's "oldest ice" is therefore a major challenge of the ice core science community (Brook et al., 2006). A necessary first step towards this goal is to identify potential drilling sites based on available information on ice-sheet structure and accompanying age modelling (Fischer et al., 2013; Van Liefferinge and Pattyn, 2013).

The maximum age of a continuous ice core depends on several parameters (Fischer et al., 2013). Mathematically, the age $\chi$ of the ice at a level $z$ above bedrock can be written as follows:

$\chi(z)=\int \frac{D\left(z^{\prime}\right)}{a\left(z^{\prime}\right) \tau\left(z^{\prime}\right)} \mathrm{d} z^{\prime}$,

where $D(z)$ is the relative density of the material ( $<1$ for the firn and $=1$ for the ice), $a(z)$ is the accumulation rate (initial vertical thickness of a layer, in metres of ice $\left.\mathrm{yr}^{-1}\right), \tau(z)$ is the vertical thinning function, i.e. the ratio of the vertical thickness of a layer in the ice core to its initial vertical thickness at the surface, and $H$ is the total ice thickness. Increasing the maximum age $\chi_{\max }$ can be obtained by increasing $H$ or by decreasing $a$ or $\tau$. At first glance, one might select a site where $H$ is maximum and $a$ is minimum, but this neglects the importance of $\tau$, notably through basal melting. In general, $\tau$ decreases toward the bed and, in steady state, reaches the value $\mu=m / a$, where $m$ is the basal melting. $m$ is therefore a crucial parameter of the problem, as it destroys the bottom of the ice record. As ice is a good insulator, $H$ either increases the ice temperature towards melting for frozen basal ice conditions, or, when melting is present, $m$ increases with $H$ and with the geothermal flux underneath the ice sheet (Fischer et al., 2013). Consequently, "oldest-ice" sites have a better chance to exist where ice is not overly thick as to lead to basal melting (Seddik et al., 2011), yet thick enough to contain a continuous ancient accumulation. The distance of a site to the ice divide is also an important parameter. This distance influences the profile of $\tau$, which is increasingly non-linear right at a dome. Therefore, $\chi_{\max }$ can be up to 10 times larger at a dome than a few kilometres downstream (Martín and Gudmundsson, 2012). Moreover, assuming a largely constant ice sheet configuration across glacial cycles, an ice record close to the divide has travelled a shorter horizontal distance and therefore has a better chance of being stratigraphically undisturbed (Fischer et al., 2013).

The depth-age profile in an ice sheet can be obtained using radar observations at VHF ranges to identify englacial reflections (e.g. Fujita et al., 1999) and trace them as isochrones across the ice sheet (Cavitte et al., 2016; Siegert et al., 1998). Until now, such analysis has been restricted to the top three-fourths of the ice thickness in East Antarctica. However, depth-age information from internal layers can be used in conjunction with ice flow models and age information from ice cores to extrapolate down to the bed. Radar observations allow estimates of poorly known ice-sheet parameters, such as the geothermal flux (Shapiro and Ritzwoller, 2004) and past changes in the position of ice domes and divides.

The Dome $\mathrm{C}$ sector is one of the target areas for the "oldest-ice" challenge and has a number of distinct benefits over other regions: it has already been heavily surveyed by geophysical techniques (Cavitte et al., 2016; Siegert et al., 1998; Tabacco et al., 1998), a reference age scale has been developed through the existing ice core work (Bazin et al., 2013; Veres et al., 2013) and it is logistically accessible from nearby Concordia Station. In this study, we concentrate on airborne radar transects (Fig. 1), which are all related to the EDC ice core. These data resolve the bed (Young et al., 2017) and internal isochrones (Cavitte et al., 2017) and are suitable for the oldest-ice search (Winter et al., 2017). The isochrones are dated up to about $366 \mathrm{kyr}$ BP using the most recent AICC2012 chronology established for the EDC ice core (Bazin et al., 2013; Veres et al., 2013). We extrapolate the age of the isochrones toward the bed using an ice flow model in order to identify potential oldest-ice sites along these transects. We also build maps of surface accumulation rate, geothermal flux and of a linearity parameter of the ver- 


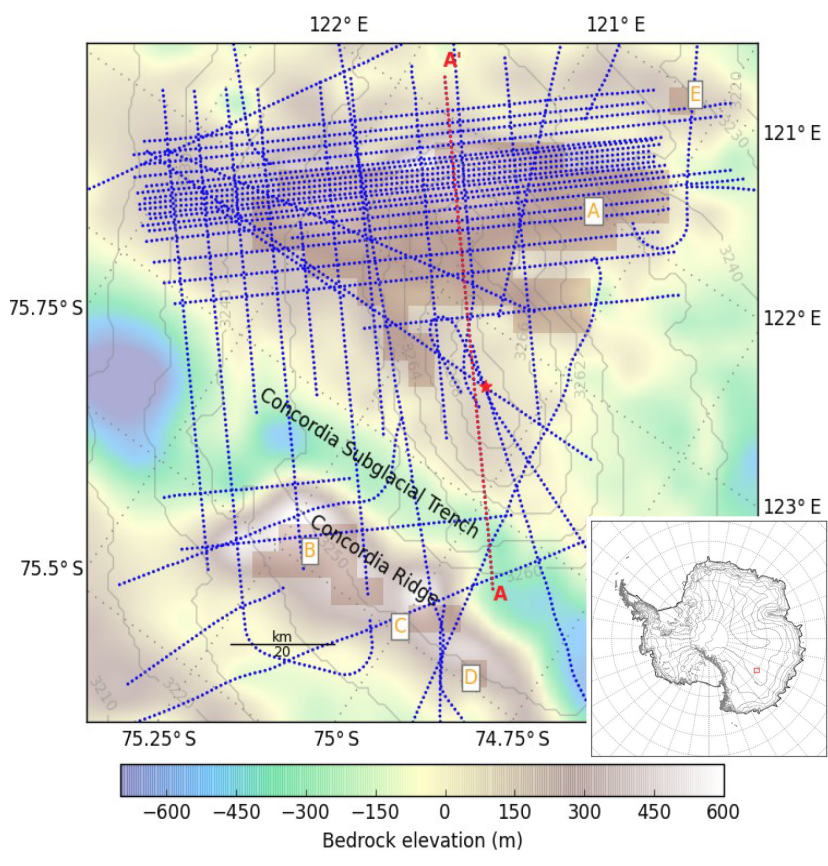

Figure 1. Radar transects used in this study (dotted blue and red lines). The light colour scale represents the bedrock elevation (Fretwell et al., 2013) while the thin grey transparent lines represent the surface elevation (Fretwell et al., 2013). The red square in the inset show the location of the zoomed map around EDC. The red star is the location of the EDC drilling site. The orange squared areas are oldest-ice candidates from Van Liefferinge and Pattyn (2013). The red dotted line is the OIA/JKB2n/X45 radar line displayed in Fig. 3.

tical velocity profile. The spatial and temporal variations of surface accumulation rates are discussed in detail in a companion paper (Cavitte et al., 2017).

\section{Method}

We use a 1-D pseudo-steady (Parrenin et al., 2006) ice flow model, which assumes that the geometry, the shape of the vertical velocity profile, the ratio $\mu=m / a$ and the relative density profile are constant in time. Only a temporal factor $R(t)$ is applied to both the accumulation rate $a$ and basal melting $m$ :

$a(x, t)=\bar{a}(x) R(t)$,

$m(x, t)=\bar{m}(x) R(t)$,

where $\bar{a}(x)$ and $\bar{m}(x)$ are the temporally averaged accumulation and melting rates at a certain point $x$. Under the pseudosteady assumption, the vertical thinning function is given by

$\tau=(1-\mu) \omega+\mu$,

where $\omega$ is the horizontal flux shape function (Parrenin et al., 2006). While there is no physical reason to assume co-

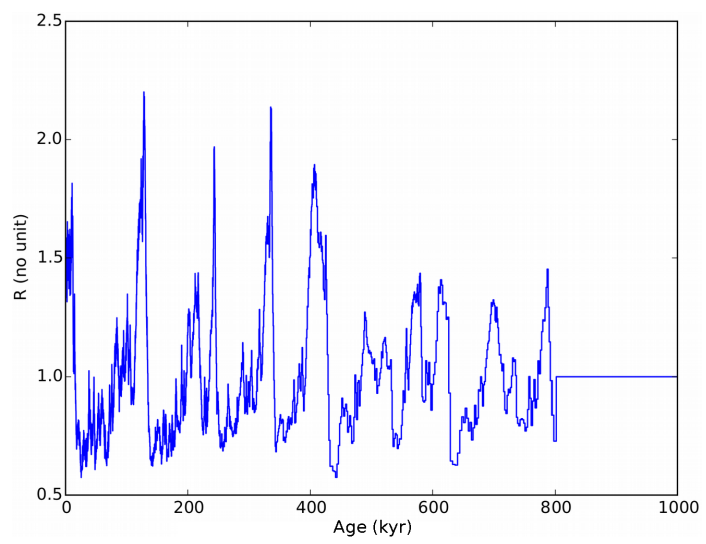

Figure 2. $R(t)$ proportionality factor applied to accumulation and melting rates (see Eq. 2). The plot is cut at $1 \mathrm{Myr}$ for better readability. $R(t)$ is based on the accumulation record at EDC for the last 800 kyr (Bazin et al., 2013; Veres et al., 2013).

variance of basal melting and surface accumulation, comparison with a transient dating model (Parrenin et al., 2007) shows errors of only $6 \%$ maximum in the evaluation of the thinning function. Moreover, the fact that there is an analytical expression for the thinning function allows one to drastically reduce the computation time, an important factor since the 1-D model needs to be applied on many locations and with many different sets of parameters. A steady age $\chi_{\text {steady }}$ is first calculated assuming a steady accumulation $\bar{a}$ and a steady melting $\bar{m}$. Then the real age $\chi$ is calculated using the following equation (Parrenin et al., 2006):

$\mathrm{d} \chi_{\text {steady }}=R(t) \mathrm{d} \chi$

$R(t)$ (Fig. 2) is directly inferred from the accumulation record of the EDC ice core (Bazin et al., 2013; Veres et al., 2013). Beyond $800 \mathrm{kyr} \mathrm{BP}$, it is assumed to be equal to 1 ; that is to say that the accumulation before $800 \mathrm{kyr} \mathrm{BP}$ is assumed equal to the average accumulation over the last $800 \mathrm{kyr}$. The horizontal flux shape function is determined using an analytical expression (Lliboutry, 1979; Parrenin et al., 2007):

$\omega(\zeta)=1-\frac{p+2}{p+1}(1-\zeta)+\frac{1}{p+1}(1-\zeta)^{p+2}$,

where $\zeta=z / H$ is the normalised vertical coordinate $(0$ at bedrock and 1 at surface) expressed in ice equivalent, and $p$ a parameter modifying the non-linearity of $\omega$ (the smaller $p$, the more non-linear $\omega$ ). This formulation assumes that there is a negligible basal sliding ratio, as is the case at EDC (Parrenin et al., 2007). This might not be the case elsewhere, but adding a basal sliding term has a similar effect as increasing the $p$ parameter for the top $\sim$ three-fourths of the ice sheet. The age of the ice at any depth is deduced from Eq. (1) using the relative density profile at EDC (Bazin et al., 2013).

To compute the basal melting, we use a simple steady-state 1-D thermal model. We solve the heat equation (neglecting 
the heat production by deformation since there is minimal horizontal shear) as follows:

$\frac{\mathrm{d}}{\mathrm{d} z}\left(k_{T} \frac{\mathrm{d} T}{\mathrm{~d} z}\right)-c \rho_{\mathrm{i}} D u_{z} \frac{\mathrm{d} T}{\mathrm{~d} z}=0$,

where $T$ is the temperature, $u_{z}$ is the vertical velocity, $\rho_{\mathrm{i}}=917 \mathrm{~kg} \mathrm{~m}^{-3}$ is the ice density (Cuffey and Paterson, $2010)$ and $k_{T}\left(\mathrm{~W} \mathrm{~m}^{-1} \mathrm{~K}^{-1}\right)$ is the thermal conductivity (Cuffey and Paterson, 2010), is given by

$k_{T}=\frac{2 k_{T}^{i} D}{3-D}$,

$k_{T}^{i}=9.828 \exp \left(-5.7 \times 10^{-3} T\right)$,

and $c\left(\mathrm{~J} \mathrm{~kg}^{-1} \mathrm{~K}^{-1}\right)$, the specific heat capacity (Cuffey and Paterson, 2010) is given by

$c=152.5+7.122 T$.

The boundary conditions are

$\left.T\right|_{z=H}=T_{\mathrm{S}}$,

$\left.T\right|_{z=0}=T_{\mathrm{f}}$ (temperate base),

or $-\left.k_{T} \frac{\mathrm{d} T}{\mathrm{~d} z}\right|_{z=0}=G_{0}$ (cold base),

where $T_{\mathrm{S}}=212.74 \mathrm{~K}$ is the average temperature at the surface assumed to be equal to the one at Dome $\mathrm{C}$ (Parrenin et al., 2013), $G_{0}$ is the geothermal flux and $T_{\mathrm{f}}$, the fusion temperature is given by Ritz (1992):

$T_{\mathrm{f}}=273.16-7.4 \times 10^{-8} P-2.4 \times 10^{-8} P^{\prime}$,

where $P^{\prime}=10^{6} \mathrm{~Pa}$ is the partial pressure of air and $P$, the pressure, is approximated by the hydrostatic pressure:

$P=\rho_{\mathrm{i}} g \int D\left(z^{\prime}\right) \mathrm{d} z^{\prime}$,

where $g=9.81 \mathrm{~m} \mathrm{~s}^{-2}$ is the gravitational acceleration. We used this formula since it gives the best agreement to the measured temperature profile at EDC (Passalacqua et al., 2017). The basal melting is given by

$m=\frac{G_{0}-G}{\rho_{\mathrm{i}} L_{\mathrm{f}}}$ (temperate base),

or $m=0$ (cold base),

where $G$ is the vertical heat flux at the base of the ice sheet and $L_{\mathrm{f}}=333.5 \mathrm{~kJ} \mathrm{~kg}^{-1}$ is the latent heat of fusion (Cuffey and Paterson, 2010).

To prevent $p$ from being $<-1$ (Eq. 5 has a singularity for $p=-1$ ), we write

$p=-1+\exp \left(p^{\prime}\right)$.

The values of $a, G_{0}$ and $p^{\prime}$ are reconstructed using a variational inverse method and using the radar isochrone constraints. The cost function to minimise is formulated using a least-squares expression:
Table 1. Age and total age uncertainty of the 18 isochrones used in this study.

\begin{tabular}{rr}
\hline Age (yr BP) & Uncertainty (yr) \\
\hline 9989 & 258 \\
38106 & 597 \\
46410 & 790 \\
73367 & 2071 \\
82014 & 1548 \\
96487 & 1745 \\
106247 & 1822 \\
121088 & 1702 \\
127779 & 1771 \\
160372 & 3581 \\
166355 & 3230 \\
200116 & 2177 \\
220062 & 3019 \\
254460 & 4025 \\
277896 & 3636 \\
327339 & 3053 \\
341476 & 4409 \\
366492 & 5838 \\
\hline
\end{tabular}

$$
\begin{aligned}
S & =\sum \frac{\left(\chi_{i}^{\text {iso }}-\chi^{\text {mod }}\left(d_{i}^{\text {iso }}\right)\right)^{2}}{\left(\sigma_{i}^{\text {iso }}\right)^{2}}+\frac{\left(p_{\text {prior }}^{\prime}-p^{\prime}\right)^{2}}{\left(\sigma^{\prime}\right)^{2}} \\
& +\frac{\left(G_{0, \text { prior }}-G_{0}\right)^{2}}{\left(\sigma^{G_{0}}\right)^{2}},
\end{aligned}
$$

where $N$ is the number of isochrones $(3 \leq N \leq 18$, see Table 1 and Fig. 3), $d_{i}^{\text {iso }}$ and $\chi_{i}^{\text {iso }}$ are the depths and ages of the isochrones respectively, $\sigma_{i}^{\text {1so }}$ is the confidence interval on their age and $\chi^{\text {mod }}$ is the modelled age. $p_{\text {prior }}^{\prime}=\ln (1+1.97)$ is the a priori estimates of $p^{\prime}$, inferred from the age-scale model of the EDC ice core (Parrenin et al., 2007) and $\sigma^{p^{\prime}}=2$ is its standard deviation, chosen to be sufficiently large to allow for a large range of $p^{\prime}$ values. $G_{0, \text { prior }}=51 \mathrm{~mW} \mathrm{~m}^{-2}$ is the a priori estimate of the geothermal flux calculated from satellite magnetic data (Fox Maule et al., 2005; Purucker, 2013), and from analysis of the heat required to maintain melting above subglacial lakes (Siegert and Dowdeswell, 1996). $\sigma^{G_{0}}=25 \mathrm{~mW} \mathrm{~m}^{-2}$ is the uncertainty in the geothermal flux (Fox Maule et al., 2005; Purucker, 2013); the total uncertainty of the age of isochrones $\sigma^{\text {iso }}$ is composed of (1) the uncertainty in the depth of the traced isochrones (Cavitte et al., 2016), transferred in age, and (2) the uncertainty of the AICC2012 age of the isochrone at the EDC site.

To solve the least-squares problem formulated in Eq. (16), we used a standard Metropolis-Hastings algorithm (Hastings, 1970; Metropolis et al., 1953) with 1000 iterations. This allows one not only to obtain a most probable modelling scenario, but also to quantify the posterior probability distribu- 
(a)

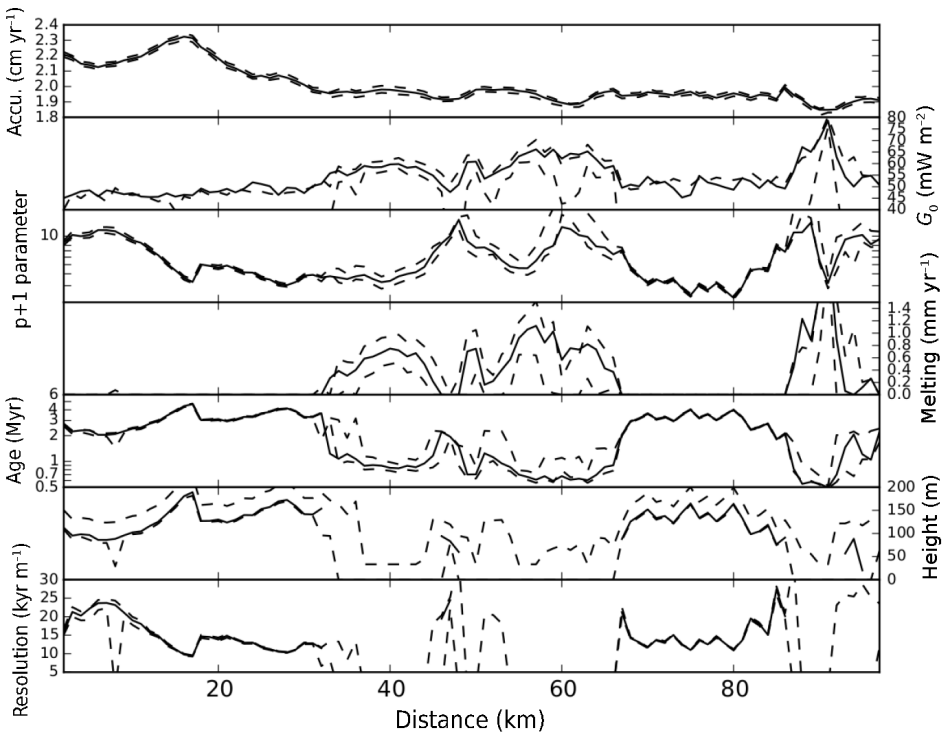

(b)

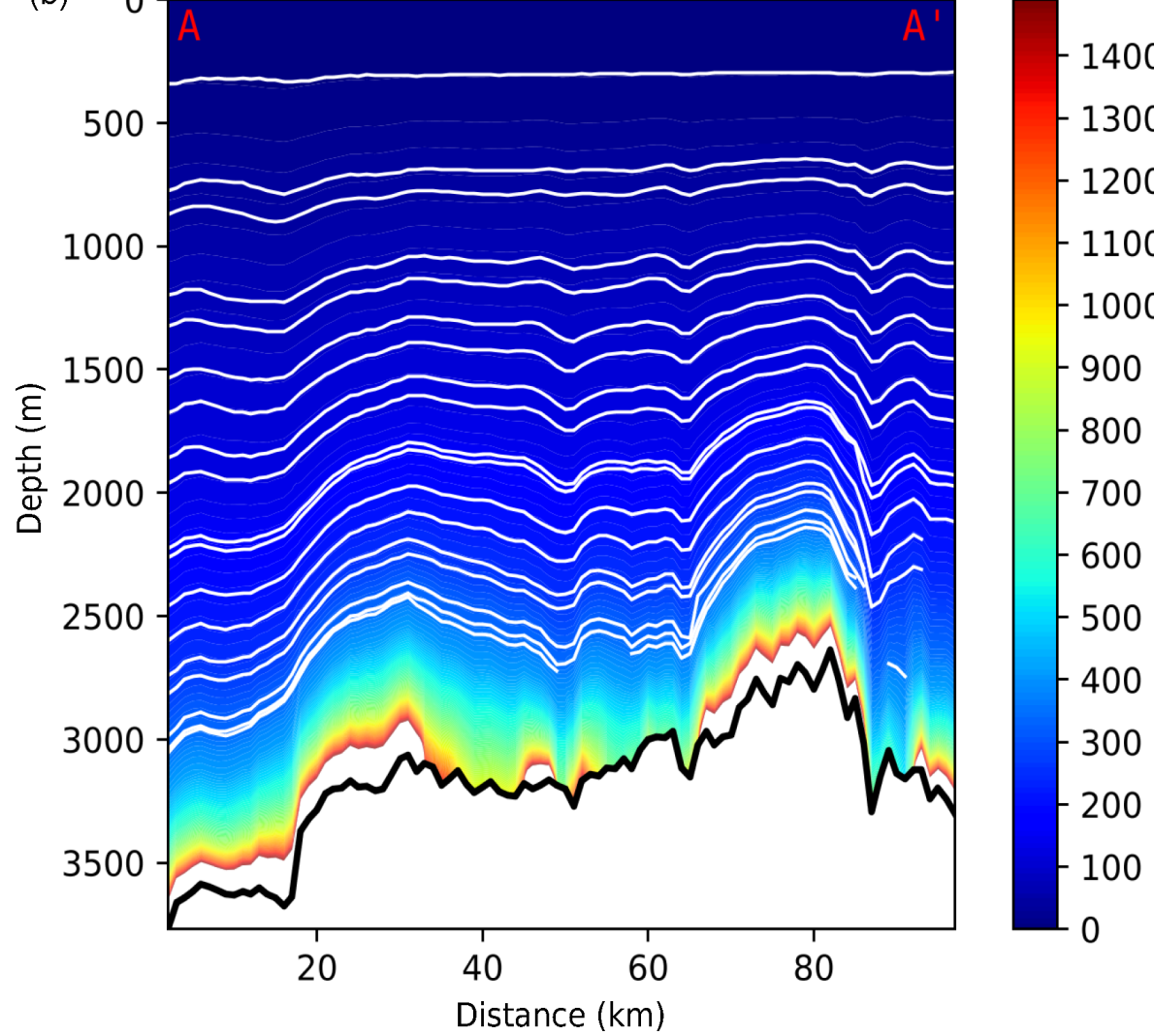

Figure 3. One-dimensional ice flow simulation along the OIA/JKB2n/X45 radar transect (see red dotted line in Fig. 1 for location). (a) Various inferred parameters (plain lines) as well as their 15th and 85th percentiles (dashed lines). From top to bottom panels: average surface accumulation rate, geothermal heat flux, $p+1$ parameter of the velocity profile, average basal melting, bottom age $60 \mathrm{~m}$ above bedrock, height above bed of the 1.5 Myr isochrone and resolution of the $1.5 \mathrm{Myr}$ isochrone. (b) Modelled age (in colour scale; white is for ages older than 1.5 Myr), together with observed isochrones (in white) and bed (in thick black). Note the two main oldest-ice candidates at distance $25 \mathrm{~km}$ (North Patch, NP) and at distance $75 \mathrm{~km}$ (Little Dome C Patch, LDCP). 
tion, in particular the confidence intervals or the modelled quantities.

\section{Results and discussions}

In our forward modelling, we used the 1-D pseudo-steady assumption. This assumption is very convenient numerically because in this case, there is an analytical expression for the thinning function (Eq. 3). Therefore, there is no need to use a costly Lagrangian scheme, following the trajectories of ice particles. Of course, the reality is more complex than the pseudo-steady assumption because the temporal variations in melting and accumulation rates are not related and are not the same for each point in space. In Parrenin et al. (2007), we used a more complex age model with a ratio $\mu$ and with an ice thickness allowed to vary in time. The results are very similar with the pseudo-steady model. This is because melting is small compared to the accumulation, and the variations in ice thickness are small compared to the total ice thickness. Regarding the spatial pattern of accumulation, we assumed that it is stable in time, which is roughly confirmed by the inversion of internal layers (Cavitte et al., 2017). Moreover, the 1-D assumption dominates the uncertainty since we do not take into account horizontal advection and dome movement. Therefore, we suggest the pseudo-steady assumption is good enough for a 1-D model.

An example age profile along the OIA/JKB2n/X45 radar transect (see Fig. 1 for its position) is displayed in Fig. 3. From these profiles, maps of the modelled age at $60 \mathrm{~m}$ above the bed, minimum age at $60 \mathrm{~m}$ above the bed (at $85 \%$ confidence level), the height above the bed of the $1.5 \mathrm{Ma}$ isochrone and temporal resolution at $1.5 \mathrm{Myr}$ are displayed in Fig. 4. We use $60 \mathrm{~m}$ above the bed as this is the height at EDC below which the ice becomes disturbed such that it cannot be interpreted stratigraphically (Tison et al., 2015). The modelled basal melting $m$ and inferred steady accumulation rate $a$, geothermal flux $G_{0}$ and $p^{\prime}$ parameter of the vertical velocity profile are displayed in Fig. 5.

The bottom age inferred at EDC at $3200 \mathrm{~m}$ is $785 \mathrm{kyr}$, which is remarkably close to the age of $\sim 820 \mathrm{kyr}$ inferred from the analysis of the ice core (Bazin et al., 2013; Veres et al., 2013). This $35 \mathrm{kyr}$ difference represent a depth mismatch of $24 \mathrm{~m}$. This is a confirmation of the method used, despite its assumptions (i.e. 1-D, pseudo-steady, Lliboutry velocity profile).

There are two main regions where the basal age is modelled to be older than 1.5 Myr. The first one is situated close to Little Dome C (LDC), $\sim 40 \mathrm{~km}$ south-west of EDC. In this region that we call LDC Patch (LDCP), the ice thickness is several hundred metres lower than at EDC, thus reducing the likelihood of basal melting. The second region is $10-30 \mathrm{~km}$ north-east of EDC in the direction of the coast, at a place where the ice thickness is comparable to the one at EDC but with a lower geothermal flux. We call this re- gion "North Patch" (NP). In those two oldest-ice spots, the height above the bed of the $1.5 \mathrm{Myr}$ isochrone is modelled to be greater than $150 \mathrm{~m}$. The temporal resolution at $1.5 \mathrm{Myr}$ is $\sim 10 \mathrm{kyr} \mathrm{m}^{-1}$, which is sufficient to resolve the main climatic periods (Fischer et al., 2013).

Our LDCP area is generally consistent with Candidate A of Van Liefferinge and Pattyn (Van Liefferinge and Pattyn, 2013) although our area is smaller and constrained to the subglacial highlands under LDC. Van Liefferinge and Pattyn (2013) did not find a candidate at NP. However, the geothermal heat flux maps they relied on have a lower spatial resolution than the details we examine here. Our model does not predict very old ages for Candidates B-E of Van Liefferinge and Pattyn (2013), although the 1-D assumption is problematic in those areas since ice particles experienced very different ice thickness conditions along their path.

One possible limitation of our simple ice sheet model is that it does not allow for a layer of accreted ice. We argue that there are no discernable accretion features in the UTIG radargrams, although it is possible that the accretion features do not show up in the basal layer which is difficult to interpret.

We now examine the other variables inferred from the inversion. Basal melting is of course negligible at these two oldest-ice spots. Melting is, however, significant around EDC (which is consistent with known basal melting at this place), on the other side of LDC and on the bed ridge adjacent to the Concordia Subglacial Trench (called here the Concordia Ridge), consistent with the observation of subglacial lakes (Wright and Siegert, 2012; Young et al., 2017). While it is surprising that basal melting is so large across the ridge of the bed, where the ice thickness is smaller, the 1-D assumption is probably invalid in this region, since the ice has been significantly advected horizontally over regions with very different basal conditions (i.e. over the wet-based Concordia Subglacial Trench and then over the adjacent Concordia Ridge which likely has a frozen base). The average surface accumulation rate shows a large-scale north-east-south-west gradient probably linked to a precipitation gradient. It also shows small-scale variations linked to surface features and probably due to snow redistribution by wind. The spatial and temporal variations of accumulation are the subject of a companion paper to this study (Cavitte et al., 2017). For the geothermal flux, it should be noted that its reconstruction is only relevant when there is some basal melting (i.e. a temperate base). When the base is cold, its evaluation mainly relies on the prior used for the least-squares cost function. Indeed, below the threshold of zero melting, further decreasing the geothermal flux has no effect on the basal melting, and therefore no effect on the modelled age. In the EDC region, the geothermal flux is estimated around $60 \mathrm{~mW} \mathrm{~m}^{-2}$. A high geothermal flux of $\sim 80 \mathrm{~mW} \mathrm{~m}^{-2}$ is also estimated on the ridge adjacent to the Concordia Subglacial Trench. Again, these results should be taken with caution since they could be an artifact due to the 1-D assumption used. The $p$ value inferred 

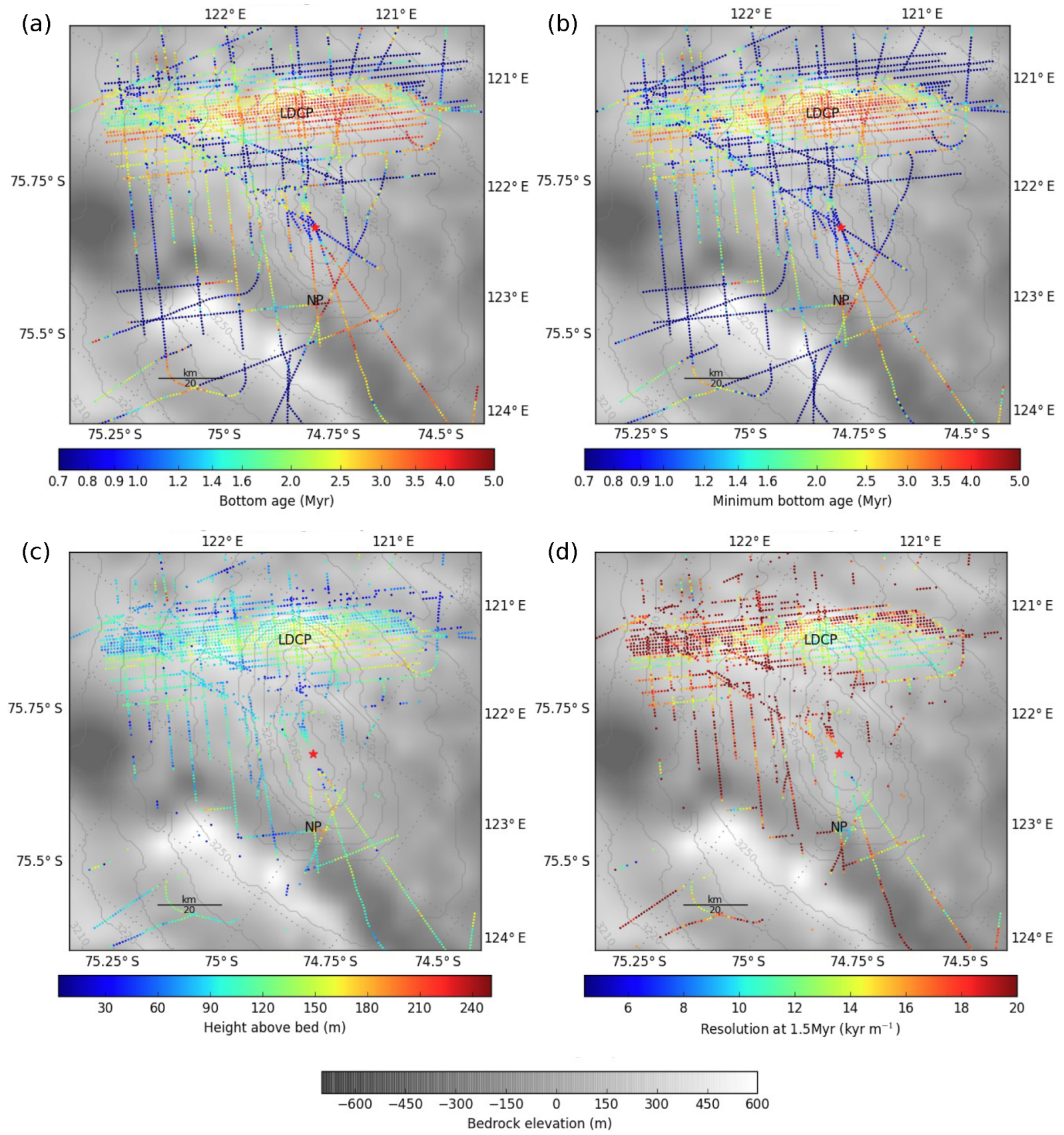

Figure 4. Various bottom-age-related variables along the radar transects, in vivid colours. The bedrock and surface elevations (greyscale and isolines respectively) are shown as in Fig. 1. LDCP and NP are the two old ice patches that we discuss in this study. (a) Modelled bottom age at $60 \mathrm{~m}$ above bedrock. (b) Minimum bottom age at $60 \mathrm{~m}$ above bedrock with $85 \%$ confidence. (c) Height above bed of the $1.5 \mathrm{Myr}$ isochrone. (d) Temporal resolution for the $1.5 \mathrm{Myr}$ modelled isochrone.

at EDC is 2.63, compatible with the value of $1.97 \pm 0.93$ inferred from the inversion of the EDC age/depth profile (Parrenin et al., 2007). Over the LDC relief, our method infers low $p^{\prime}$ values, in agreement with the absence of basal melting and therefore basal sliding. This value increases over the Concordia Subglacial Trench and on the south-west side of the LDC bedrock relief, which is probably a sign of increased basal sliding due to the presence of melt water at the ice/bed interface. The very low $p^{\prime}$ values on the Concordia Ridge adjacent to the Concordia Subglacial Trench are again probably an artifact of the 1-D assumption. 

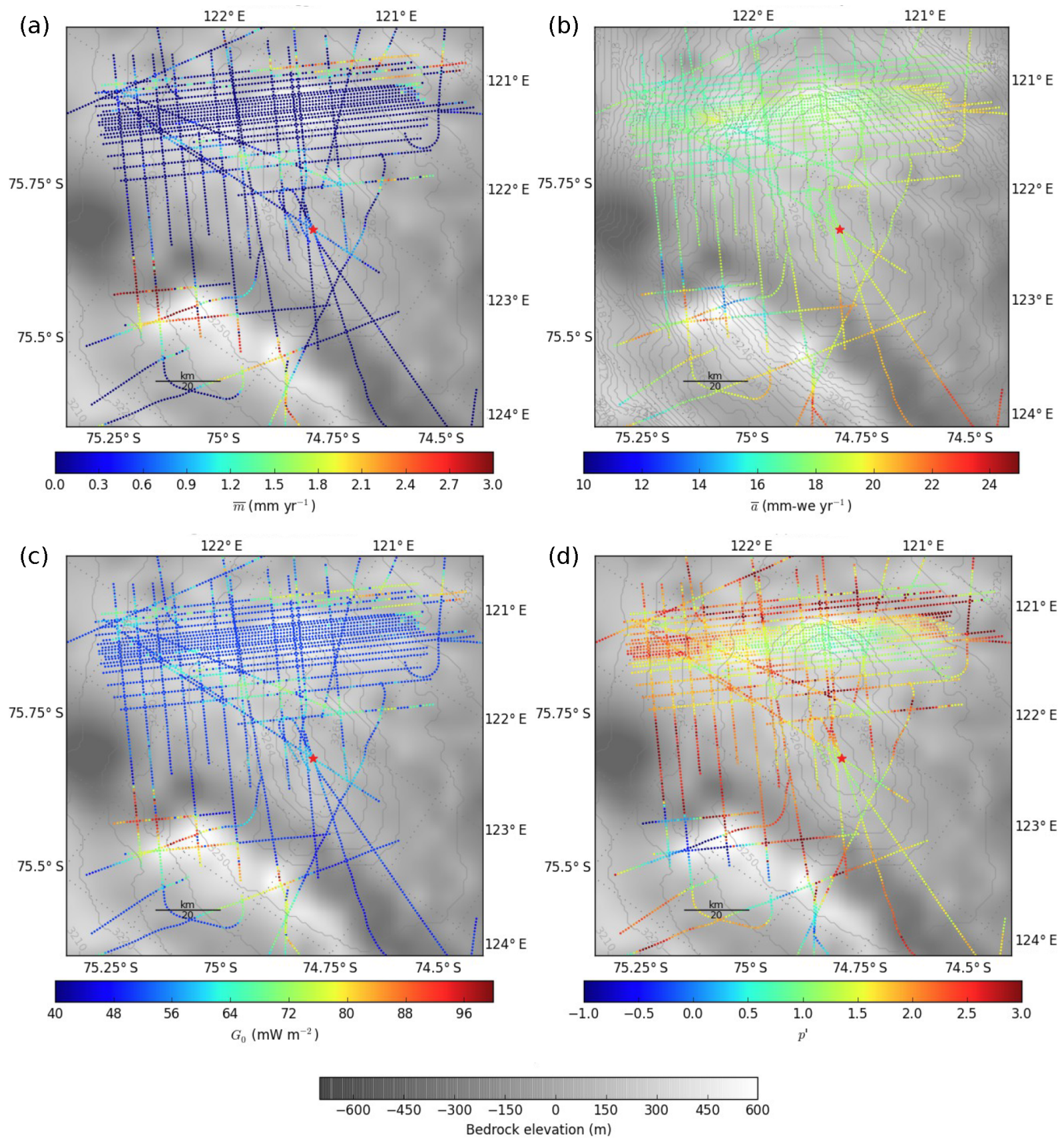

Figure 5. Various variables reconstructed by the inverse method along the radar transects, in vivid colour scale. The bedrock and surface elevations (greyscale and isolines respectively) are shown as in Fig. 1. (a) Modelled temporally averaged basal melting. (b) Inferred temporally averaged surface accumulation rate. (c) Inferred geothermal flux. (d) Inferred $p^{\prime}$ vertical velocity parameter.

\section{Conclusions}

We developed a simple 1-D thermo-mechanical model constrained by radar observations to infer the age in an ice sheet. We identified two areas where the age of basal ice should exceed 1.5 Myr. They are located only a few tens of kilometres away from the French-Italian Concordia station, which could provide excellent logistical support for deep drilling.
The first area, LDCP, is close to a secondary dome and on a bedrock massif where ice thickness is only $\sim 2700 \mathrm{~m}$. It is located only $\sim 40 \mathrm{~km}$ away from the Concordia station in south-westerly direction. The second area, NP, is $10-30 \mathrm{~km}$ north-east of Concordia in the direction of the coast. These "oldest-ice" candidates will be subject to further field studies to verify their suitability. A 3-D model approach would be necessary to study the effect of horizontal advection. Using 
the shape of the isochrones, which is better constrained than their absolute age, would shed more light on this problem. The possibility of a layer of stagnant ice should also be investigated. Ultimately, in situ study of the age of the bottommost ice at these sites will soon be feasible at minimal operational costs using new rapid access drilling technologies (Chappellaz et al., 2012; Schwander et al., 2014), which will provide in situ measurements to further assess the age of the basal ice and the integrity of the ice core stratigraphy. If successful, this next step will open an exciting opportunity for expanding the EDC records $\sim 700 \mathrm{kyr}$ further back in time, which could help reveal the mechanisms controlling the last major climate reorganisation across the MPT.

Data availability. The code used for this inference, called IsoInv, is hosted on the github platform. The inferred parameters are hosted by the PANGAEA facility.

Competing interests. The authors declare that they have no conflict of interest.

Acknowledgements. We thank the glaciology group at University of Washington and F. Gillet-Chaulet at IGE for helpful discussions. Operational support was provided by the Australian Antarctic Division, the Institut polaire français Paul-Emile Victor (IPEV) and the Italian Antarctic Program (PNRA and ENEA). We thank the staff of Concordia Station and the Kenn Borek Air flight crew. Additional support was provided by the French ANR Dome A project (ANR-07-BLAN-0125). Funding was provided by the French AGIR project "OldestIce", the National Science Foundation grant PLR-0733025 (ICECAP), the Australian Antarctic Division project 4346, the G. Unger Vetlesen Foundation and NERC grant NE/D003733/1. This work was supported by the Australian Government's Cooperative Research Centres Programme through the Antarctic Climate \& Ecosystems Cooperative Research Centre (ACE CRC). This publication was generated in the frame of Beyond EPICA-Oldest Ice (BE-OI). The project has received funding from the European Union's Horizon 2020 research and innovation programme under grant agreement no. 730258 (BE-OI CSA). It has received funding from the Swiss State Secretariat for Education, Research and Innovation (SERI) under contract number 16.0144. It is furthermore supported by national partners and funding agencies in Belgium, Denmark, France, Germany, Italy, Norway, Sweden, Switzerland, the Netherlands and the United Kingdom. Logistic support is mainly provided by AWI, BAS, ENEA and IPEV. The opinions expressed and arguments employed herein do not necessarily reflect the official views of the European Union funding agency, the Swiss Government or other national funding bodies. This is BE-OI publication number 2 and UTIG contribution 3133

Edited by: Kenny Matsuoka

Reviewed by: Ralf Greve and Howard Conway

\section{References}

Abe-Ouchi, A., Saito, F., Kawamura, K., Raymo, M. E., Okuno, J., Takahashi, K., and Blatter, H.: Insolation-driven 100,000-year glacial cycles and hysteresis of ice-sheet volume, Nature, 500, 190-193, 2013.

Bazin, L., Landais, A., Lemieux-Dudon, B., Toyé Mahamadou Kele, H., Veres, D., Parrenin, F., Martinerie, P., Ritz, C., Capron, E., Lipenkov, V., Loutre, M.-F., Raynaud, D., Vinther, B., Svensson, A., Rasmussen, S. O., Severi, M., Blunier, T., Leuenberger, M., Fischer, H., Masson-Delmotte, V., Chappellaz, J., and Wolff, E.: An optimized multi-proxy, multi-site Antarctic ice and gas orbital chronology (AICC2012): 120-800 ka, Clim. Past, 9, 17151731, https://doi.org/10.5194/cp-9-1715-2013, 2013.

Berger, A., Li, X. S., and Loutre, M. F.: Modelling northern hemisphere ice volume over the last $3 \mathrm{Ma}$, Quaternary Sci. Rev., 18, 1-11, 1999.

Bintanja, R. and Van de Wal, R. S. W.: North American ice-sheet dynamics and the onset of 100,000-year glacial cycles, Nature, 454, 869-872, 2008.

Brook, E. J., Wolff, E., Dahl-Jensen, D., Fischer, H., and Steig, E. J.: The future of ice coring: International partnerships in Ice Core Sciences (IPICS), PAGES News, 14, 6-10, 2006.

Cavitte, M. G. P., Blankenship, D. D., Young, D. A., Schroeder, D. M., Parrenin, F., Lemeur, E., Macgregor, J. A., and Siegert, M. J.: Deep radiostratigraphy of the East Antarctic plateau: connecting the Dome C and Vostok ice core sites, J. Glaciol., 62, 323-334, https://doi.org/10.1017/jog.2016.11, 2016.

Cavitte, M. G. P., Parrenin, F., Ritz, C., Young, D. A., Blankenship, D. D., Frezzotti, M., and Roberts, J. L.: Stable accumulation patterns around Dome C, East Antarctica, over the last glacial cycle, The Cryosphere Discuss., https://doi.org/10.5194/tc-2017-71, in review, 2017.

Chappellaz, J., Alemany, O., Romanini, D., and Kerstel, E.: The IPICS "oldest ice" challenge: a new technology to qualify potential site, Ice Snow, 4, 57-64, 2012.

Clark, P. U., Archer, D., Pollard, D., Blum, J. D., Rial, J. A., Brovkin, V., Mix, A. C., Pisias, N. G., and Roy, M.: The middle Pleistocene transition: characteristics, mechanisms, and implications for long-term changes in atmospheric $p \mathrm{CO}_{2}$, Quaternary Sci. Rev., 25, 3150-3184, 2006.

Cuffey, K. M. and Paterson, W. S. B.: The physics of glaciers, Academic Press, Amsterdam, 2010.

Elderfield, H., Ferretti, P., Greaves, M., Crowhurst, S., McCave, I. N., Hodell, D., and Piotrowski, A. M.: Evolution of Ocean Temperature and Ice Volume Through the Mid-Pleistocene Climate Transition, Science, 337, 704-709, https://doi.org/10.1126/science.1221294, 2012.

Fischer, H., Schmitt, J., Lüthi, D., Stocker, T. F., Tschumi, T., Parekh, P., Joos, F., Köhler, P., Völker, C., Gersonde, R., Barbante, C., Floch, M. L., Raynaud, D., and Wolff, E.: The role of Southern Ocean processes in orbital and millennial $\mathrm{CO}_{2}$ variations - A synthesis, Quaternary Sci. Rev., 29, 193-205, https://doi.org/10.1016/j.quascirev.2009.06.007, 2010.

Fischer, H., Severinghaus, J., Brook, E., Wolff, E., Albert, M., Alemany, O., Arthern, R., Bentley, C., Blankenship, D., Chappellaz, J., Creyts, T., Dahl-Jensen, D., Dinn, M., Frezzotti, M., Fujita, S., Gallee, H., Hindmarsh, R., Hudspeth, D., Jugie, G., Kawamura, K., Lipenkov, V., Miller, H., Mulvaney, R., Parrenin, F., Pattyn, F., Ritz, C., Schwander, J., Steinhage, D., van Om- 
men, T., and Wilhelms, F.: Where to find 1.5 million yr old ice for the IPICS "Oldest-Ice" ice core, Clim. Past, 9, 2489-2505, https://doi.org/10.5194/cp-9-2489-2013, 2013.

Fox Maule, C., Purucker, M. E., Olsen, N., and Mosegaard, K.: Heat Flux Anomalies in Antarctica Revealed by Satellite Magnetic Data, Science, 309, 464-467, https://doi.org/10.1126/science.1106888, 2005.

Fretwell, P., Pritchard, H. D., Vaughan, D. G., Bamber, J. L., Barrand, N. E., Bell, R., Bianchi, C., Bingham, R. G., Blankenship, D. D., Casassa, G., Catania, G., Callens, D., Conway, H., Cook, A. J., Corr, H. F. J., Damaske, D., Damm, V., Ferraccioli, F., Forsberg, R., Fujita, S., Gim, Y., Gogineni, P., Griggs, J. A., Hindmarsh, R. C. A., Holmlund, P., Holt, J. W., Jacobel, R. W., Jenkins, A., Jokat, W., Jordan, T., King, E. C., Kohler, J., Krabill, W., Riger-Kusk, M., Langley, K. A., Leitchenkov, G., Leuschen, C., Luyendyk, B. P., Matsuoka, K., Mouginot, J., Nitsche, F. O., Nogi, Y., Nost, O. A., Popov, S. V., Rignot, E., Rippin, D. M., Rivera, A., Roberts, J., Ross, N., Siegert, M. J., Smith, A. M., Steinhage, D., Studinger, M., Sun, B., Tinto, B. K., Welch, B. C., Wilson, D., Young, D. A., Xiangbin, C., and Zirizzotti, A.: Bedmap2: improved ice bed, surface and thickness datasets for Antarctica, The Cryosphere, 7, 375-393, https://doi.org/10.5194/tc-7-375-2013, 2013.

Fujita, S., Maeno, H., Uratsuka, S., Furukawa, T., Mae, S., Fujii, Y., and Watanabe, O.: Nature of radio-echo layering in the Antarctic ice sheet detected by a two-frequency experiment, J. Geophys. Res., 104, 13013-13024, 1999.

Hastings, W. K.: Monte Carlo sampling methods using Markov chains and their application, Biometrika, 57, 97-109, 1970.

Hönisch, B., Hemming, N. G., Archer, D., Siddall, M., and McManus, J. F.: Atmospheric carbon dioxide concentration across the mid-Pleistocene transition, Science, 324, 1551-1554, 2009.

Imbrie, J. Z., Imbrie-Moore, A., and Lisiecki, L. E.: A phase-space model for Pleistocene ice volume, Earth Planet. Sc. Lett., 307, 94-102, https://doi.org/10.1016/j.epsl.2011.04.018, 2011.

Jouzel, J. and Masson-Delmotte, V.: Deep ice cores: the need for going back in time, Quaternary Sci. Rev., 29, 3683-3689, https://doi.org/10.1016/j.quascirev.2010.10.002, 2010.

Jouzel, J., Masson-Delmotte, V., Cattani, O., Dreyfus, G., Falourd, S., Hoffmann, G., Minster, B., Nouet, J., Barnola, J. M., Chappellaz, J., Fischer, H., Gallet, J. C., Johnsen, S., Leuenberger, M., Loulergue, L., Luethi, D., Oerter, H., Parrenin, F., Raisbeck, G., Raynaud, D., Schilt, A., Schwander, J., Selmo, E., Souchez, R., Spahni, R., Stauffer, B., Steffensen, J. P., Stenni, B., Stocker, T. F., Tison, J. L., Werner, M., and Wolff, E. W.: Orbital and Millennial Antarctic Climate Variability over the Past 800,000 Years, Science, 317, 793-796, https://doi.org/10.1126/science.1141038, 2007.

Laskar, J., Robutel, P., Joutel, F., Gastineau, M., Correia, A. C. M., and Levrard, B.: A long-term numerical solution for the insolation quantities of the Earth, Astron. Astrophys., 428, 261-285, https://doi.org/10.1051/0004-6361:20041335, 2004.

Lisiecki, L. E. and Raymo, M. E.: A Plio-Pleistocene Stack of 57 Globally Distributed Benthic $\delta^{18} \mathrm{O}$ Records, Paleoceanography, 20, PA1003, https://doi.org/10.1029/2004PA001071, 2005.

Lliboutry, L.: A critical review of analytical approximate solutions for steady state velocities and temperature in cold ice sheets, $\mathrm{Z}$. Gletscherkd. Glazialgeol., 15, 135-148, 1979.
Loulergue, L., Schilt, A., Spahni, R., Masson-Delmotte, V., Blunier, T., Lemieux, B., Barnola, J. M., Raynaud, D., Stocker, T. F., and Chappellaz, J.: Orbital and millennial-scale features of atmospheric $\mathrm{CH}_{4}$ over the past 800,000 years, Nature, 453, 383-386, 2008.

Lüthi, D., Floch, M. L., Bereiter, B., Blunier, T., Barnola, J.-M., Siegenthaler, U., Raynaud, D., Jouzel, J., Fischer, H., Kawamura, K., and Stocker, T. F.: High-resolution carbon dioxide concentration record 650,000-800,000 years before present, Nature, 453, 379-382, 2008.

Martín, C. and Gudmundsson, G. H.: Effects of nonlinear rheology, temperature and anisotropy on the relationship between age and depth at ice divides, The Cryosphere, 6, 1221-1229, https://doi.org/10.5194/tc-6-1221-2012, 2012.

Martínez-Garcia, A., Rosell-Melé, A., Jaccard, S. L., Geibert, W., Sigman, D. M., and Haug, G. H.: Southern Ocean dust-climate coupling over the past four million years, Nature, 476, 312-315, 2011.

Metropolis, N., Rosenbluth, A. W., Rosenbluth, M. N., Teller, A. H., and Teller, E.: Equations of state calculations by fast computing machines, J. Chem. Phys., 21, 1087-1092, 1953.

Parrenin, F. and Paillard, D.: Terminations VI and VIII $(\sim 530$ and $\sim 720 \mathrm{kyr} B$ P) tell us the importance of obliquity and precession in the triggering of deglaciations, Clim. Past, 8, 2031-2037, https://doi.org/10.5194/cp-8-2031-2012, 2012.

Parrenin, F., Hindmarsh, R. C. H., and Rémy, F.: Analytical solutions for the effect of topography, accumulation rate and lateral flow divergence on isochrone layer geometry, J. Glaciol., 52, 191-202, 2006.

Parrenin, F., Dreyfus, G., Durand, G., Fujita, S., Gagliardini, O., Gillet, F., Jouzel, J., Kawamura, K., Lhomme, N., MassonDelmotte, V., Ritz, C., Schwander, J., Shoji, H., Uemura, R., Watanabe, O., and Yoshida, N.: 1-D-ice flow modelling at EPICA Dome C and Dome Fuji, East Antarctica, Clim. Past, 3, 243-259, https://doi.org/10.5194/cp-3-243-2007, 2007.

Parrenin, F., Masson-Delmotte, V., Köhler, P., Raynaud, D., Paillard, D., Schwander, J., Barbante, C., Landais, A., Wegner, A., and Jouzel, J.: Synchronous change of atmospheric $\mathrm{CO}_{2}$ and Antarctic temperature during the last deglacial warming, Science, 339, 1060-1063, 2013.

Passalacqua, O., Ritz, C., Parrenin, F., Urbini, S., and Frezzotti, M.: Geothermal heat flux and basal melt rate in the Dome $\mathrm{C}$ region inferred from radar reflectivity and thermal modelling, The Cryosphere Discuss., https://doi.org/10.5194/tc-2017-23, in review, 2017.

Pollard, D. and DeConto, R. M.: Modelling West Antarctic ice sheet growth and collapse through the past five million years, Nature, 458, 329-332, 2009.

Purucker, M.: Geothermal heat flux data set based on low resolution observations collected by the CHAMP satellite between 2000 and 2010, and produced from the MF-6 model following the technique described in Fox Maule et al. (2005), available at: http://websrv.cs.umt.edu/isis/images/c/ c8/Antarctica_heat_flux_5km.nc (last access: 22 October 2017), 2013.

Raymo, M. E., Lisiecki, L. E., and Nisancioglu, K. H.: PlioPleistocene ice volume, Antarctic climate, and the global $\delta^{18} \mathrm{O}$ record, Science, 313, 492-495, 2006. 
Ritz, C.: Un modèle thermo-mécanique d'évolution pour le bassin glaciaire antarctique Vostok-glacier Byrd: sensibilité aux valeurs des paramètres mal connus, Thèse d'état, Univ. J. Fourier, Grenoble, France, 1992.

Schwander, J., Marending, S., Stocker, T. F., and Fischer, H.: RADIX: a minimal-resources rapid-access drilling system, Ann. Glaciol., 55, 34-38, 2014.

Seddik, H., Greve, R., Zwinger, T., and Placidi, L.: A full Stokes ice flow model for the vicinity of Dome Fuji, Antarctica, with induced anisotropy and fabric evolution, The Cryosphere, 5, 495508, https://doi.org/10.5194/tc-5-495-2011, 2011.

Shakun, J. D., Clark, P. U., He, F., Marcott, S. A., Mix, A. C., Liu, Z., Otto-Bliesner, B., Schmittner, A., and Bard, E.: Global warming preceded by increasing carbon dioxide concentrations during the last deglaciation, Nature, 484, 49-54, 2012.

Shapiro, N. M. and Ritzwoller, M. H.: Inferring surface heat flux distributions guided by a global seismic model: particular application to Antarctica, Earth Planet. Sc. Lett., 223, 213-224, 2004.

Siegert, M. J. and Dowdeswell, J. A.: Spatial variations in heat at the base of the Antarctic ice sheet from analysis of the thermal regime above subglacial lakes, J. Glaciol., 42, 501-509, 1996.

Siegert, M. J., Hodgkins, R., and Dowdeswell, J. A.: A chronology for the Dome $\mathrm{C}$ deep ice-core site through radio-echo layer Correlation with the Vostok Ice Core, Antarctica, Geophys. Res. Lett., 25, 1019-1022, https://doi.org/10.1029/98GL00718, 1998.

Singer, B. and Brown, L. L.: The Santa Rosa Event: ${ }^{40} \mathrm{Ar} /{ }^{39} \mathrm{Ar}$ and paleomagnetic results from the Valles rhyolite near Jaramillo Creek, Jemez Mountains, New Mexico, Earth Planet. Sc. Lett., 197, 51-64, 2002.

Tabacco, I. E., Passerini, A., Corbelli, F., and Gorman, M.: Determination of the surface and bed topography at Dome C, East Antarctica, J. Glaciol., 44, 185-191, 1998.

Tison, J.-L., de Angelis, M., Littot, G., Wolff, E., Fischer, H., Hansson, M., Bigler, M., Udisti, R., Wegner, A., Jouzel, J., Stenni, B., Johnsen, S., Masson-Delmotte, V., Landais, A., Lipenkov, V., Loulergue, L., Barnola, J.-M., Petit, J.-R., Delmonte, B., Dreyfus, G., Dahl-Jensen, D., Durand, G., Bereiter, B., Schilt, A., Spahni, R., Pol, K., Lorrain, R., Souchez, R., and Samyn, D.: Retrieving the paleoclimatic signal from the deeper part of the EPICA Dome C ice core, The Cryosphere, 9, 1633-1648, https://doi.org/10.5194/tc-9-1633-2015, 2015.

Tzedakis, P. C., Crucifix, M., Mitsui, T., and Wolff, E. W.: A simple rule to determine which insolation cycles lead to interglacials, Nature, 542, 427-432, 2017.
Tziperman, E. and Gildor, H.: On the mid-Pleistocene transition to 100-kyr glacial cycles and the asymmetry between glaciation and deglaciation times, Paleoceanography, 18, 1-8, 2003.

Van Liefferinge, B. and Pattyn, F.: Using ice-flow models to evaluate potential sites of million year-old ice in Antarctica, Clim. Past, 9, 2335-2345, https://doi.org/10.5194/cp-9-23352013, 2013.

Veres, D., Bazin, L., Landais, A., Toyé Mahamadou Kele, H., Lemieux-Dudon, B., Parrenin, F., Martinerie, P., Blayo, E., Blunier, T., Capron, E., Chappellaz, J., Rasmussen, S. O., Severi, M., Svensson, A., Vinther, B., and Wolff, E. W.: The Antarctic ice core chronology (AICC2012): an optimized multiparameter and multi-site dating approach for the last 120 thousand years, Clim Past, 9, 1733-1748, https://doi.org/10.5194/cp9-1733-2013, 2013.

Wang, Y., Cheng, H., Edwards, R. L., Kong, X., Shao, X., Chen, S., Wu, J., Jiang, X., Wang, X., and An, Z.: Millennial- and orbital-scale changes in the East Asian monsoon over the past 224,000 years, Nature, 451, 1090-1093, 2008.

Winter, A., Steinhage, D., Arnold, E. J., Blankenship, D. D., Cavitte, M. G. P., Corr, H. F. J., Paden, J. D., Urbini, S., Young, D. A., and Eisen, O.: Comparison of measurements from different radio-echo sounding systems and synchronization with the ice core at Dome C, Antarctica, The Cryosphere, 11, 653-668, https://doi.org/10.5194/tc-11-653-2017, 2017.

Wolff, E. W., Fischer, H., Fundel, F., Ruth, U., Twarloh, B., Littot, G. C., Mulvaney, R., Röthlisberger, R., de Angelis, M., Boutron, C. F., Hansson, M., Jonsell, U., Hutterli, M. A., Lambert, F., Kaufmann, P., Stauffer, B., Stocker, T. F., Steffensen, J. P., Bigler, M., Siggaard-Andersen, M. L., Udisti, R., Becagli, S., Castellano, E., Severi, M., Wagenbach, D., Barbante, C., Gabrielli, P., and Gaspari, V.: Southern Ocean sea-ice extent, productivity and iron flux over the past eight glacial cycles, Nature, 440, 491-496, 2006.

Wright, A. and Siegert, M.: A fourth inventory of Antarctic subglacial lakes, Antarct. Sci., 24, 659-664, https://doi.org/10.1017/S095410201200048X, 2012.

Young, D. A., Roberts, J. L., Ritz, C., Frezzotti, M., Quartini, E., Cavitte, M. G. P., Tozer, C. R., Steinhage, D., Urbini, S., Corr, H. F. J., van Ommen, T., and Blankenship, D. D.: High-resolution boundary conditions of an old ice target near Dome C, Antarctica, The Cryosphere, 11, 1897-1911, https://doi.org/10.5194/tc11-1897-2017, 2017. 